\title{
Preliminary considerations on the external morphology Plantago major L. leaves from natural populations exposed to different environmental conditions
}

\author{
VELIČKOVIĆ MIROSLAVA ${ }^{1}$ \\ TOŠKOVIĆ DOBRIVOJE \\ ${ }^{1}$ Marije Bursać No. 15/6, 11080 Zemun, Serbia \\ E-mail:miravelbgd@sezampro.rs \\ ${ }^{2}$ Academy of Engineering Sciences of Serbia (AESS), \\ University of Belgrade, Zeleni venac 2-III, 11000 \\ Belgrade, Serbia \\ E-mail: dtosk02009@gmail.com

\section{Abbreviations} \\ leaf-blade apical width $\quad=($ AW $)$ \\ leaf-blade length $\quad=(\mathrm{LL})$ \\ leaf size $\quad=(\mathrm{LS})$ \\ leaf width $\quad=(\mathrm{LW})$ \\ leaf shape $\quad=(\mathrm{LW} / \mathrm{LL})$ \\ the distance from the midrib \\ to the neighboring vein $\quad=(\mathrm{MV})$ \\ vein distances within a leaf $=(\mathrm{VD})$
}

Received November 24, 2014

Revised July 22, 2015.

Accepted July 28, 2015

\begin{abstract}
Background and purpose: Allometry is the study of the relationship of body size to shape, anatomy, physiology and behavior. Plants displaying allometric relationships between certain traits across different environments should have higher relative fitness then plants lacking these allometric relationships. We hypothesized that there are differences in external morphology between Plantago major L. (ssp. major) leaves exposed to different environmental conditions with variations for the leaf characters analysed.
\end{abstract}

Materials and methods: Seven, linear dimensions on each leaf: leafblade apical width (AW), leaf-blade length (LL), leaf size (LS), leaf width $(L W)$, leafshape (LW/LL), the distance from the midrib to the neighboring vein $(M V)$ and vein distances within a leaf $(V D)$ were analysed. Here, besides analyzing allometric relationships between the common plantain leaves exposed to different environmental conditions, morphological data were also used for a regression analysis and for a cluster analysis.

Results: In the reference area (Vinci village) leaves have significantly longer $L L$ and they are significantly broader compared with leaves from polluted site (Pančevo). At both sites, LL decreased relatively to LS (i.e. negative allometry is character specific). This study also revealed that VD and $L W / L L$ are developmentally and functionally integrated P. major leaf characters. Moreover, VD is under more selective pressure to adapt to current environmental conditions than $L W / L L$.

Conclusions: Obtained data showed that leaf size is significantly related to both, developmental and environmental conditions. This indicates that plant species such as Plantago major L. (ssp. major) should be considered as reliable bioindicators in environmental quality monitoring studies.

\section{INTRODUCTION}

Alometry was first outlined by Snell, Thompson and Huxley $(1,2,3)$, A who indicated that allometry is the study of the relationship of body size to shape, anatomy, physiology and behavior.

The three recognized types of allometry are: static, ontogenic and evolutionary. The static allometry (i.e. "size allometry") reflects variations among individuals of the same age, ontogenetic allometry is due to growth processes, and evolutionary allometry is the result of comparative analysis of allometric patterns among different populations/ species (4). 
As is known, the anatomical and physiological implications of size in plants differing in growth form, taxonomic group and environmental setting $(5,6,7)$.

Applications of allometry to plant biology have primarily consisted in the development of correlative relationships among size-related variables for application to agriculture, forestry and ecology $(6,8)$. Plant size is a product of resource availability (plants in resource-rich habitats tend to be larger then in resource-poor habitats) and age (old plants tend to be larger then young plants). Therefore, the measures of size in plants are important indicators of plant fitness (9). As suggested by Bonser and Aarssen (9) plants displaying allometric relationships between certain traits across different environments should have higher relative fitness then plants lacking in these allometric relationships.

Here, besides analyzing allometric relationships between the common plantain Plantago major L. (ssp. major) leaves exposed to different environmental conditions, morphological data were also used for a regression analysis and for a cluster analysis.

In the present study, we addressed the following question: Are there morphological differences between natural populations of Plantago major L. (ssp. major) leaves investigated for the characters analysed?

Leaves provide a complementary and more reliable source of data for evaluating scaling issues then do whole plants (9). Long-term field observations on plants showed that measures of leaf morphological characters are important tools for evaluating biological responses to stress $(10,11,13,14,15,16)$. This is because exposure to stressful conditions is commonly associated with an increase in phenotypic and genetic variation in organism traits by affecting developmental abnormalities in the morphology of an organism (17).

We hypothesized that there are differences in external morphology between Plantago major L. (ssp. major) leaves exposed to different environmental conditions with variations for the characters analysed.

\section{MATERIALS AND METHODS}

\section{Species characteristics}

The genus Plantago comprises 270 species. The cosmopolitan and common weed, Plantago major L. (Plantaginaceae) has warranted attention. It has been extensively studied (18). Plantago major L. originated from Europe, but has become cosmopolitan. In Serbia, Plantago major L. (ssp. major) is a widely distributed species (19). This species can be found along roadsides, in gardens and open grasslands, but also in wet and muddy environments. It is an herbaceous perennial plant $(30-70 \mathrm{~cm}$ tall) with a rosette of leaves. Each leaf is oval or elliptic with five to nine conspicuous veins. Flowers are greenish or yellowish white and bisexual. Plantago major $\mathrm{L}$. is wind-pollinated and self-compatible. According to El-Bakatoushi (20), self-pollination is unlikely because Plantago major L. is protogynous and flowering acropetal. This means that stigmas are exerted from flowers one to three days before pollen is shed. The seeds, sticky when wet, are often dispersed by animals. Also, they can remain viable for up to 60 years in the soil. In tests with Plantago major L., a range of pharmacological activities has been found including antibiotic, anti-inflammatory, anti-ulcerogenic activities, anti-oxidant, diuretic immunomodulatory, and wound healing. Active compounds include caffeic acid derivatives, flavonoids, iridoid glycosides, lipids, polysaccharides, and terpenoids. In natural habitats, under optimal conditions Plantago major L. may live up to 15 years (21).

\section{Study areas}

The sampling design in the present study was based on a procedure proposed by (Veličković, 2007). Two sites were used as sampling areas (Figure 1). Pančevo site represented a polluted environment, whereas Vinci village was considered as a reference, unpolluted one. The two sites are approximately $150 \mathrm{~km}$ apart.

The Pančevo site ( $\left.44^{0} 53^{\prime} 00.00^{\prime \prime} \mathrm{N}, 20^{\circ} 40^{\prime} 00.00^{\prime \prime} \mathrm{E}\right)$ is located $20 \mathrm{~km}$ northeast of Belgrade. It is an industrial town located in the province of Vojvodina in the republic of Serbia. The industrial area (covers 290 hectares) is the site of a large petrochemical complex and fuel storage site in Serbia and includes an ammonia plant ("HIPAzotara", founded in 1962), a factory for chemical fertilizers ("HIP Petrohemija", founded in 1975), and a

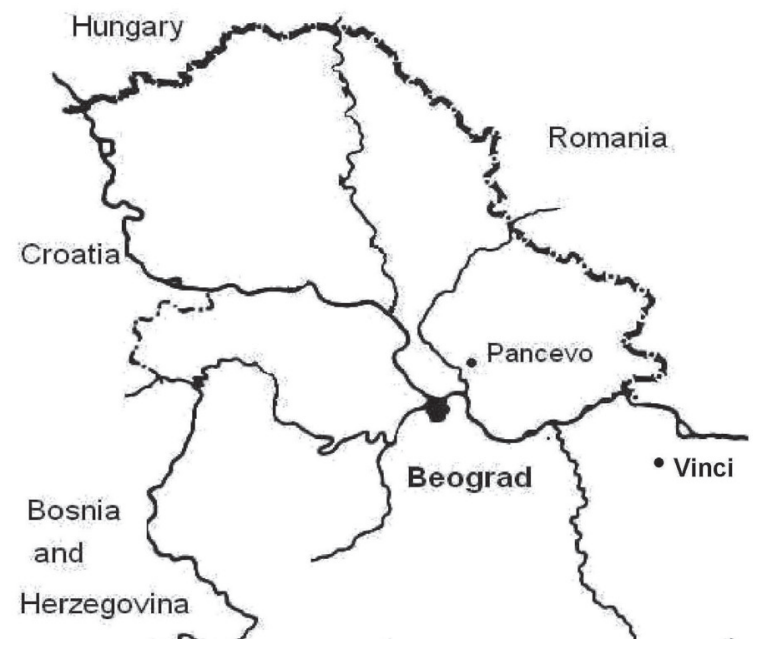

Fig. 1. Location of the sampling sites. 
crude oil refinery ("NIS Oil Refinery", founded in 1968). In Serbia, Pančevo site is known for exceeding the legally-permitted quantity of dangerous and harmful chemical compounds (22). In the Pančevo site there are some chemical compounds (together with their metabolites and unwanted by-products) which represent the most dangerous chemical pollutants with long-term negative effects on environment, human health and living organisms $(14,23,24)$. Pančevo is extremely windy; it is exposed to the effects of two kinds of winds (southeastern and northwestern) which directly bring pollutants from industrial zone towards the residential areas.

However, it is important that in Pančevo site, plants were not exposed to the negative effects of the chemical pollutants only; plants (leaves) were also exposed to the negative effects of a diverse range of both biotic and abiotic factors.

The Vince village is a natural, woodland area located $6 \mathrm{~km}$ to the west of the Golubac site $\left(4^{0} 38^{\prime} 00.00^{\prime \prime} \mathrm{N}\right.$, $\left.21^{0} 37^{\prime} 00.00^{\prime} \mathrm{E}\right)$, in the National Park “Đerdap", far from any known possibility of contamination. The National Park "Đerdap" is the largest Serbian National park $\left(630.08 \mathrm{~km}^{2}\right)$. It is under protection since 1983 , and is considered an area of great national and international significance (25).

\section{Sampling design}

One hundred fully developed leaves which are not damaged or affected by a shadow of a neighbouring leaf (one largest leaf per plant; each leaf with five major veins) were chosen per sampling area. Leaves were sampled along transects of approximately 1 ha, during July of 2012. On the basis of Janković and Gajić (19), all the plants analysed in this study belong to the same subspecies (Plantago major L. ssp. major).

The collecting sessions were ten days apart. Whole plants were collected in plastic bags from both sampling sites. Fresh leaves were tagged, washed and dried between sheets of filter paper, measured and then analysed.

The study was based on seven leaf characters, Figure 2. Five out of these seven characters namely: (LW) which is the distance from the midrib to the right and left margins at the leaf's widest point; (VD) which is the distance between veins in the left and right side of a leaf, measured at a leaf's widest point), (MV) which is the distance from the midrib to the neighboring vein, measured at a leaf's widest point in the left and in the right side of a leaf; (AW) which is the distance from the midrib to the tip of the exterior vein and (LL) which is the distance from the base of the leafblade to the apex (tip of leaf) also were all used in recently published papers $(11,13,15)$. The remaining traits were: (LS) which is the distance from the base of the petiole to the apex of the leaf-blade and (LW/LL) or leaf shape which is calculated as leaf width to leaf-blade length ratio $(16,26)$.

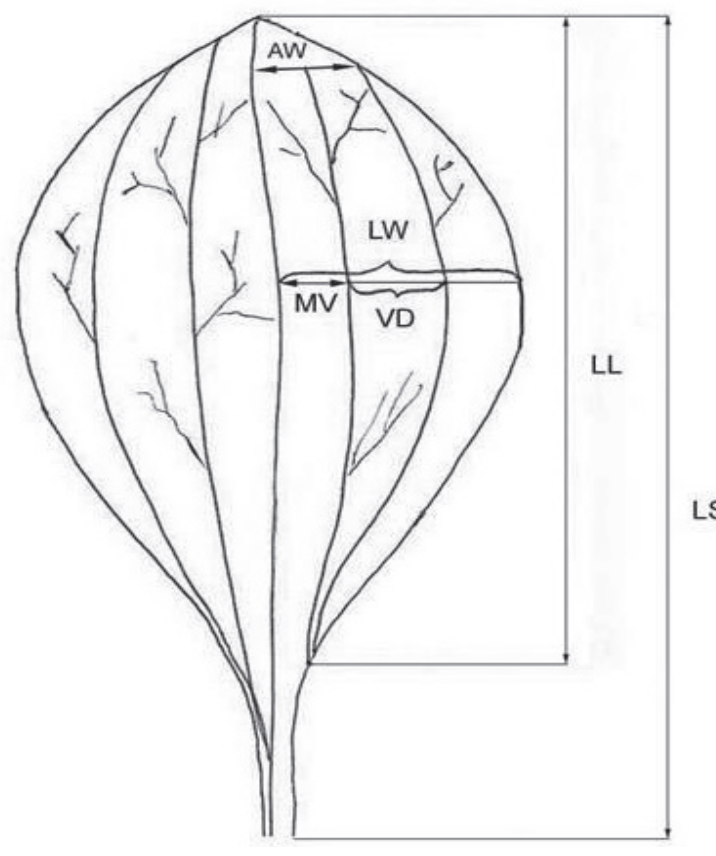

Fig. 2. Diagram of a Plantago major L. (ssp. major) leaf showing leaf width $(L W)$, vein distances within a leaf $(V D)$, the distance from the midrib to the neighboring vein in the left and in the right side of a leaf, measured at a leaf's widest point $(M V)$, leaf-blade apical width $(A W)$, leaf-blade length (LL). These leaf characters are bilaterally symmetrical and only measurements of the right sides of these characters are shown in the diagram. Leaf size (LS) and width to leaf-blade length ratio (LW/LL) are also used leafcharacters for numerical analysis.

For each bilaterally symmetrical leaf parameter (LW, VD, MV, AW and LL) trait size was calculated as the average value for value of the parameter on leaf's right side (R) plus value of the parameter on leaf's left side (L): $(\mathrm{R}+\mathrm{L}) / 2$.

All measurements ( $0.1 \mathrm{~mm}$ accuracy) were performed by the same person (M. V.) and are given in centimeters $(\mathrm{cm})$. All analyses (regression, allometry and cluster analyses) were performed using the same plants (leaves).

\section{Descriptive statistics}

Descriptive statistics for the Plantago major L. (ssp. major) leaf traits were presented in Table 1. Deviation from normality for each leaf character was assessed using the Kolmogorov-Smirnov test of normality. Because normality was rejected in certain cases (see Results), mean values of the characters were compared between sites by means of Kolmogorov-Smirnov two-sample (nonparametric) test.

Following Petz (27), coefficient of variation values (CVs) were calculated for each character measured and then compared between sites. Because CV value is expressed as a percent (abbreviated CV\%), the differences between CVs were estimated as the differences between percentages. 


\section{Statistical treatments for regression and allometry analyses}

As recommended by Verwijst and Wen (26), to test for linear regression relationships and for allometric patterns of each leaf parameter relative to LS, data were $\log _{10}$ transformed and a least-square regression in a linear model was used.

Models based on allometric scaling, which are regression with $\log _{10}$-transformed data, have been noted as superior to regression based models that have used untransformed data (28).

In (29), authors have suggested that an important reason for using regression is to test whether the relationship (described by the slope of the regression line on a plot of $\log$ - transformed data) between morphometric variables is isometric or allometric.

According to (29), there are two ways to test for isometric versus allometric change: 1) predicting the isometric slope and 2) to test whether isometric slope falls between the $\pm 95 \%$ confidence limits of $\log _{10}$ transformed data.

Thus, if the isometric slope falls between the $\pm 95 \%$ confidence limits of $\log _{10}$ transformed data then isometric slope and the actual regression slope are not significantly different (29).

Here, we have predicted that isometric slope is 1 (i.e. one). There are three possible patterns of allometric relationships: Isometry where the actual slope value do not show a significant difference from 1 , indicating direct proportionality between the leaf parameter and LS; positive allometry $(+A)$ where the slope values are significantly greater then 1 indicating that the variable increased relatively to LS; negative allometry (-A) where the slope values are significantly smaller then 1 and the variable decreased relatively to LS (30).

The significance of the slopes (allometric coefficients) was tested by means of a $t$-test (31). According to (30), slope values of each leaf parameter versus LS, for Plantago major L. (ssp. major) leaves analysed per each site, were compared by performing Student's $t$-test. In order to compare the regression coefficients $(\mathrm{R})$ of each leaf parameter versus LS between samples, $z$-test was performed (32).

\section{Statistical treatments for hierarchical agglomerative cluster analysis}

A hierarchical clustering of variables, based on an agglomerative method, was also applied on log-transformed data. Thus, hierarchical cluster analysis was performed for detecting clustering in the data.

The unweighted pair-group method (UPGMA) was used as a joining algorithm to define how distances between clusters are measured. In this method, the distance between two clusters was calculated as the average dis- tance between all pairs of objects in the two different clusters. Furthermore, the Euclidean distance was chosen to compare clusters. To visualize the result of a hierarchical clustering of variables, a tree structure graph known as a dendrogram was performed.

Statistica version 5.0 (Stat. Soft., Inc., Tulsa, USA) and Microsoft Excel ${ }^{\oplus}$ (v. Office 2003) were used for all statistical analyses except for the hierarchical cluster analysis, for which the SPSS ${ }^{\circledast}$ Data Analysis Package version 10.0 (SPSS inc. Chicago, USA) was used.

\section{RESULTS}

The normality was rejected for nine out of fourteen distributions considered: $(0.153 \leq \mathrm{d} \leq 0.327,0.01 \leq \mathrm{p} \leq 0.05)$ (Table 1).

The leaves from the reference area (Vinci village) had significantly higher LW, VD, MV, AW and LL values (Kolmogorov-Smirnov nonparametric test results, all $\mathrm{p}<0.05)$, compared with leaves from the polluted site.

The leaves from the reference area (Vinci village) had slightly, but not significantly higher LW/LL values compared with the leaves from the polluted area (Pančevo site).

Coefficients of variation (CV\%) were calculated for each trait separately by site (Table 1 ). The CV values ranged from 6.537-29.082(\%) in Pančevo site and from 4.352-60.741(\%) in Vinci village. The most variable leaf character was $\mathrm{VD}\left(\mathrm{CV}_{\mathrm{VD}}=60.741 \%\right)$ and the most stable leaf character was $\mathrm{LS}\left(\mathrm{CV}_{\mathrm{LS}}=4.352 \%\right)$ both in the reference area.

The obtained results showed that there were significant differences between Plantago major L. (ssp. major) populations for the leaf width $\left(\mathrm{P}_{\mathrm{LW}}<0.05\right)$ and the vein distances within a leaf $\left(\mathrm{P}_{\mathrm{VD}}<0.01\right)$. For both the leaf characters, the reference area (Vinci village) exhibited significantly higher $\mathrm{CV}$ values then the polluted site (Pančevo).

\section{Regression analysis}

Regression analysis on log-transformed data (Figure 3) pointed that in Vinci village reference area) there were statistically significant and positive linear relationships between leaf characters such as LW, VD, LW/LL versus LS.

No significant differences in regression coefficients were found between the two samples analysed, for all $p>0.05$ (for LW: $z=-0.810$; for VD: $z=-0.828$; for MV: $\mathrm{z}=-0.311$; for AW: $\mathrm{z}=-0.333$, for $\mathrm{LL}: \mathrm{z}=0.494$, for $\mathrm{LW} /$ LL: $\mathrm{z}=-0.885)$.

\section{Allometry analysis}

Results on allometry analysis are presented in Table 2. The relationship between leaf characters versus leaf size showed that all the three types of allometric relationships were observed in the reference area (Vinci village) site. Thus, 
Table 1. Summary statistics for Plantago major L. (ssp major) leaf measurements in Pančevo (polluted) and Vinci village (reference) sites.

\begin{tabular}{|lccccccccc|}
\hline Sample $(\mathrm{n}=100)$ & trait & Mean $( \pm$ SE) & Min.-Max. & SD & Variance & Skewness $( \pm$ SE $)$ & Kurtosis $( \pm$ SE $)$ & K-S & CV $(\%)$ \\
\hline Pančevo site & LW & $2.804( \pm 0.047)$ & $2.050-4.050$ & 0.473 & 0.224 & $0.847( \pm 0.241)$ & $0.281( \pm 0.478)$ & 0.135 & 17.358 \\
& VD & $0.863( \pm 0.033)$ & $0.300-1.750$ & 0.331 & 0.109 & $0.626( \pm 0.241)$ & $-0.149( \pm 0.478)$ & 0.113 & 14.375 \\
& MV & $0.617( \pm 0.009)$ & $0.350-0.900$ & 0.089 & 0.008 & $-0.043( \pm 0.241)$ & $2.057( \pm 0.478)$ & $0.236^{* *}$ & 14.833 \\
& AW & $2.783( \pm 0.089)$ & $0.700-4.450$ & 0.887 & 0.788 & $-1.200( \pm 0.241)$ & $0.691( \pm 0.478)$ & $0.327^{*}$ & 29.082 \\
& LL & $11.430( \pm 0.168)$ & $9.350-17.950$ & 1.677 & 2.813 & $1.906( \pm 0.241)$ & $5.225( \pm 0.478)$ & 0.117 & 15.108 \\
Vinci village & LS & $18.778( \pm 0.123)$ & $10.200-21.300$ & 1.229 & 1.511 & $-3.216( \pm 0.241)$ & $23.335( \pm 0.478)$ & $0.153^{*}$ & 6.537 \\
& LW/LL & $0.250( \pm 0.006)$ & $0.147-0.388$ & 0.057 & 0.003 & $0.667( \pm 0.241)$ & $-0.042( \pm 0.478)$ & 0.117 & 23.554 \\
& LW & $3.188( \pm 0.098)$ & $2.000-5.850$ & 0.983 & 0.966 & $1.084( \pm 0.241)$ & $0.158( \pm 0.478)$ & $0.223^{* *}$ & 30.834 \\
& VD & $0.968( \pm 0.059)$ & $0.050-2.250$ & 0.588 & 0.346 & $0.542( \pm 0.241)$ & $-0.920( \pm 0.478)$ & $0.172^{* *}$ & 60.741 \\
& MV & $0.691( \pm 0.012)$ & $0.400-1.050$ & 0.123 & 0.015 & $1.130( \pm 0.241)$ & $1.183( \pm 0.478)$ & $0.212^{* *}$ & 17.800 \\
& AW & $3.084( \pm 0.062)$ & $0.700-4.500$ & 0.615 & 0.378 & $-2.107( \pm 0.241)$ & $6.861( \pm 0.478)$ & $0.296^{* *}$ & 19.942 \\
& LL & $11.930( \pm 0.0116)$ & $9.700-17.400$ & 1.160 & 1.345 & $2.469( \pm 0.241)$ & $9.711( \pm 0.478)$ & $0.165^{* *}$ & 9.723 \\
& LS & $18.636( \pm 0.081)$ & $16.600-20.800$ & 0.811 & 0.658 & $-0.031( \pm 0.241)$ & $-0.127( \pm 0.478)$ & 0.092 & 4.352 \\
& LW/LL & $0.270( \pm 0.0009)$ & $0.150-0.535$ & 0.089 & 0.008 & $1.030( \pm 0.241)$ & $0.206( \pm 0.478)$ & $0.177^{* *}$ & 32.963 \\
\hline
\end{tabular}

Mean $=$ mean value, $\mathrm{SE}=$ standard error, Min. = minimum, Max. = maximum, $\mathrm{SD}=$ standard deviation, Var. $=$ variance, $\mathrm{K}-\mathrm{S}=\mathrm{Kolmogorov}-\mathrm{Smirnov}$ test of normality, CV $=$ coefficient of variation, ${ }^{*}=\mathrm{p}<0.05,{ }^{* *}=\mathrm{p}<0.01$.

Table 2. Results obtained are from the regression analysis performed for Plantago major L. (ssp. major) leaves sampled from two sites in Serbia

\begin{tabular}{|c|c|c|c|c|c|c|c|c|}
\hline Sample & Variable & a & $\mathrm{b}$ & $\mathrm{SE}_{(\mathrm{b})}$ & SEE & $-95 \%$ & $+95 \%$ & Pattern $_{(\mathrm{b})}$ \\
\hline \multicolumn{9}{|c|}{ Pančevo site, $n=100$} \\
\hline & $\log _{10} L W$ & 0.165 & 0.217 & 0.212 & 0.704 & -0.205 & 0.639 & $-\mathrm{A}^{* *}$ \\
\hline & $\log _{10} \mathrm{VD}$ & 0.078 & -0.137 & 0.516 & 0.171 & -1.159 & 0.885 & $-A^{*}$ \\
\hline & $\log _{10} M V$ & -0.307 & 0.073 & 0.200 & 0.066 & -0.323 & 0.469 & $-\mathrm{A}^{* *}$ \\
\hline & $\log _{10}$ AW & 0.106 & 0.237 & 0.624 & 0.207 & -1.001 & 1.475 & I \\
\hline & $\log _{10} L L$ & $0.636^{* *}$ & 0.328 & 0.173 & 0.057 & -0.015 & 0.671 & $-\mathrm{A}^{* *}$ \\
\hline & $\log _{10} \mathrm{LW} / \mathrm{LL}$ & -0.471 & -0.111 & 0.294 & 0.097 & -0.693 & 0.471 & $-\mathrm{A}^{* *}$ \\
\hline \multicolumn{9}{|c|}{ Vinci village, $\mathrm{n}=100$} \\
\hline & $\log _{10} L W$ & $-2.426^{* *}$ & $2.292^{* * *}$ & 0.609 & 0.115 & 1.086 & 3.498 & $+\mathrm{A}^{* *}$ \\
\hline & $\log _{10} \mathrm{VD}$ & $-6.592^{* *}$ & $5.101^{* *}$ & 1.584 & 0.318 & 1.767 & 8.435 & $+\mathrm{A}^{* *}$ \\
\hline & $\log _{10} M V$ & -0.846 & 0.535 & 0.383 & 0.072 & -0.224 & 1.292 & I \\
\hline & $\log _{10} A W$ & $1.804^{*}$ & -1.047 & 0.711 & 0.137 & -2.456 & 0.360 & $-A^{* *}$ \\
\hline & $\log _{10} L L$ & $1.004^{* * *}$ & 0.055 & 0.206 & 0.039 & -0.353 & 0.463 & $-\mathrm{A}^{* *}$ \\
\hline & $\log _{10} \mathrm{LW} / \mathrm{LL}$ & $-3.430^{* * *}$ & $2.237^{* *}$ & 0.672 & 0.127 & 0.906 & 3.568 & I \\
\hline
\end{tabular}

$\mathrm{n}=$ sample size; $\mathrm{a}=$ intercept, $\mathrm{b}=$ slope, $\mathrm{SE}_{(\mathrm{b})}=$ standard error of slope, $\mathrm{SEE}=$ standard error of estimate; $-95 \%=$ lower limit of the $95 \%$ confidence intervals for the slope, $+95 \%=$ upper limit of the $95 \%$ confidence intervals for the slope, $+\mathrm{A}=$ positive allometry, $-\mathrm{A}=$ negative allometry, $\mathrm{I}=$ isometry, ${ }^{* * *}=\mathrm{p}<0.001,{ }^{* *}=\mathrm{p}<0.01,{ }^{*}=\mathrm{p}<0.05$.

LW and VD show positive allometry; AW and LL show negative allometry, whereas MV and LW/LL ratio are isometric characters (i.e. indicating direct proportionality between each of these characters and LS).

In the polluted site (Pančevo), five leaf characters (LW, VD, MV, LL and LW/LL) show negative allometry whereas only the leaf-blade apical width is an isometric character.

The present results also indicated that, in both the sites investigated, the leaf-blade length decreased relatively to LS.

The results of a comparison between slopes (LW: $\mathrm{df}=96, \mathrm{t}=0.116, \mathrm{p}=0.908 ; \mathrm{VD}: \mathrm{df}=96, \mathrm{t}=2.974, \mathrm{p}=0.004$; 

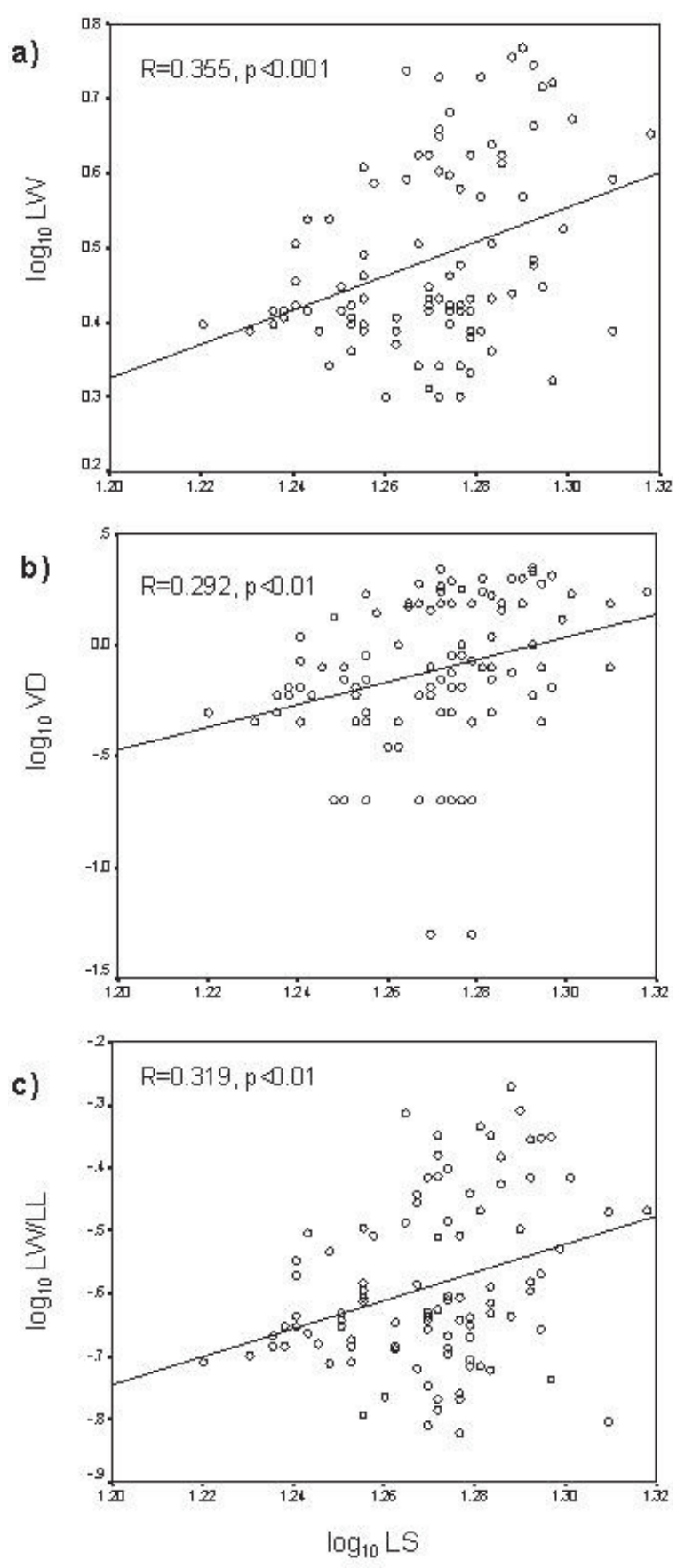

Fig. 3. Statistically significant linear relationships between leaf size (LS) versus a) leaf width $(L W), b$ ) vein distances within a leaf $(V D)$ and c) leaf width to leaf-blade length ratio ( $L W / L L)$, for Plantago major L. (ssp. major) leaves from Vinci village (reference site).

MV: $d f=96, t=1.069, p=0.288 ; A W: d f=96, t=-1.357$, $p=0.178 ; L L: d f=96, t=-1.015, p=0.313 ; L W / L L: d f=96$, $\mathrm{t}=3.201, \mathrm{p}=0.002$ ) indicated that only for VD and LW/LL (Figure 4.) the difference between the two investigated sites is statistically significant.

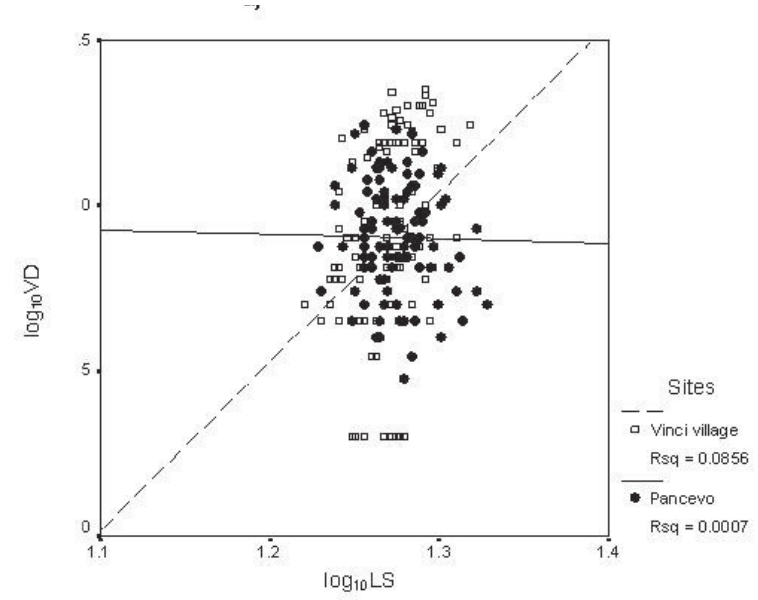

b)

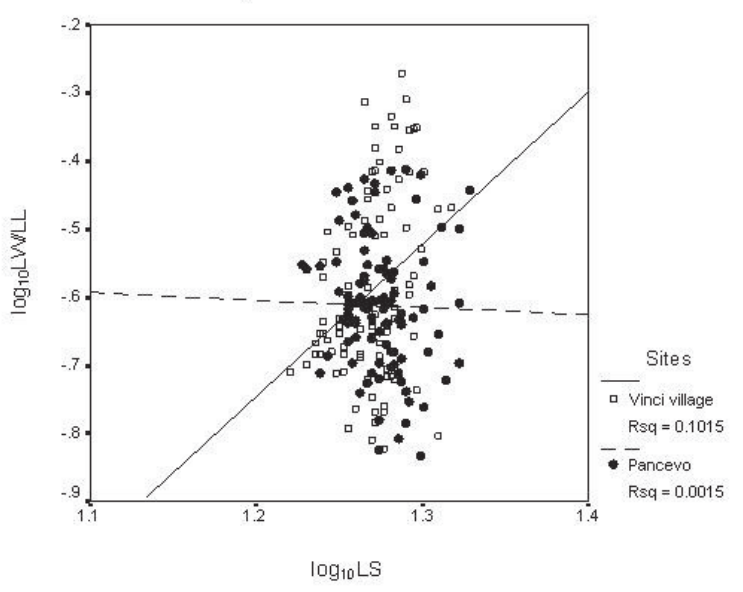

Fig. 4. Regression of characters showing significant relationships between leaf size (LS) versus a) vein distances within a leaf (VD) and b) leaf width to leaf-blade length ratio (LWILL).

\section{Cluster analysis}

The Euclidean distances among items in a data matrix consisting of variables was calculated and presented in Table 3. Furthermore, the results of the hierarchical cluster analysis for both samples are presented in Table 4. Results revealed that the cluster analysis on variables was a discrete form of factor analysis, where each variable belongs to only one cluster (factor).

Since there were seven variables (leaf characters), the cluster analysis began with seven clusters, for both samples. At Stage 1, the two variables with the smallest distance between them were clustered. Then, at Stage 2, the two variables that were next closest were combined. Accordingly, the $\mathrm{SPSS}^{\oplus}$ used this statistical procedure until all variables were grouped into one large cluster.

In the polluted site (Pančevo), at Stage 1, variable VD was clustered with variable MV. These were the two variables that have the smallest Euclidean distance (i.e. 2.132) between them. Moreover, these variables were the most 
Table 3. The Euclidean distances between pairs of variables calculated for the samples analyzed at Pancevo (polluted) and Vinci village (reference) sites in Serbia $(n=100)$.

\begin{tabular}{|c|c|c|c|c|c|c|c|}
\hline \multirow[b]{2}{*}{ Samples } & \multirow[b]{2}{*}{ Variables } & \multicolumn{5}{|c|}{ Variables } & \multirow[b]{2}{*}{$\log _{10} \mathrm{LS}$} \\
\hline & & $\log _{10} L W$ & $\log _{10} \mathrm{VD}$ & $\log _{10} \mathrm{MV}$ & $\log _{10} \mathrm{AW}$ & $\log _{10} L L$ & \\
\hline \multicolumn{8}{|c|}{ Pančevo site } \\
\hline & $\log _{10} \mathrm{VD}$ & 5.652 & & & & & \\
\hline & $\log _{10} \mathrm{MV}$ & 6.617 & 2.132 & & & & \\
\hline & $\log _{10} \mathrm{AW}$ & 2.245 & 5.986 & 6.604 & & & \\
\hline & $\log _{10} L L$ & 6.196 & 11.614 & 12.712 & 6.860 & & \\
\hline & $\log _{10} L S$ & 8.339 & 13.797 & 14.891 & 8.889 & 2.269 & \\
\hline & $\log _{10} \mathrm{LW} / \mathrm{LL}$ & 10.556 & 5.535 & 4.127 & 10.422 & 16.722 & 18.874 \\
\hline \multicolumn{8}{|c|}{ Vinci village } \\
\hline & $\log _{10} V D$ & 6.489 & & & & & \\
\hline & $\log _{10} \mathrm{MV}$ & 6.590 & 3.036 & & & & \\
\hline & $\log _{10} \mathrm{AW}$ & 1.999 & 6.994 & 6.609 & & & \\
\hline & $\log _{10} L L$ & 6.041 & 12.349 & 12.444 & 6.173 & & \\
\hline & $\log _{10} L S$ & 7.931 & 14.214 & 14.383 & 8.078 & 1.997 & \\
\hline & $\log _{10} \mathrm{LW} / \mathrm{LL}$ & 10.755 & 5.372 & 4.361 & 10.831 & 16.713 & 18.638 \\
\hline
\end{tabular}

Table 4. Results obtained are from the output of hierarchical clustering analysis calculated for the samples analyzed at Pančevo (polluted) and Vinci village (reference) sites in Serbia $(n=100)$.

\begin{tabular}{|c|c|c|c|c|c|c|c|}
\hline \multirow[b]{2}{*}{ Sample } & \multirow[b]{2}{*}{ Stage } & \multicolumn{2}{|c|}{ Cluster Combined } & \multicolumn{4}{|c|}{ Stage Cluster First Appears } \\
\hline & & Cluster 1 & Cluster 2 & Coefficients & Cluster 1 & Cluster 2 & Next Stage \\
\hline \multicolumn{8}{|c|}{ Pančevo site } \\
\hline & 1 & $\log _{10} \mathrm{VD}$ & $\log _{10} \mathrm{MV}$ & 2.132 & 0 & 0 & 4 \\
\hline & 2 & $\log _{10} L W$ & $\log _{10} A W$ & 2.245 & 0 & 0 & 5 \\
\hline & 3 & $\log _{10} L L$ & $\log _{10} L S$ & 2.269 & 0 & 0 & 5 \\
\hline & 4 & $\log _{10} V D$ & $\log _{10} L W / L L$ & 4.831 & 1 & 0 & 6 \\
\hline & 5 & $\log _{10} L W$ & $\log _{10} L L$ & 7.571 & 2 & 3 & 6 \\
\hline & 6 & $\log _{10} L W$ & $\log _{10} \mathrm{VD}$ & 11.204 & 5 & 4 & 0 \\
\hline \multicolumn{8}{|c|}{ Vinci village } \\
\hline & 1 & $\log _{10} \mathrm{LL}$ & $\log _{10} L S$ & 1.997 & 0 & 0 & 5 \\
\hline & 2 & $\log _{10} L W$ & $\log _{10} A W$ & 1.999 & 0 & 0 & 5 \\
\hline & 3 & $\log _{10} V D$ & $\log _{10} M V$ & 3.036 & 0 & 0 & 4 \\
\hline & 4 & $\log _{10} \mathrm{VD}$ & $\log _{10} L W / L L$ & 4.866 & 3 & 0 & 6 \\
\hline & 5 & $\log _{10} L W$ & $\log _{10} L L$ & 7.056 & 2 & 1 & 6 \\
\hline & 6 & $\log _{10} L W$ & $\log _{10} \mathrm{VD}$ & 11.417 & 5 & 4 & 0 \\
\hline
\end{tabular}

similar and joined to form the first cluster. Neither variable has been previously clustered (the two zeros under Cluster 1 and Cluster 2), and the next stage when the cluster containing variable VD combined with another variable (i.e. LW/LL) was Stage 4.
Furthermore, at Stage 1, variable (LL) was clustered with variable (LS). The Euclidean distance between these variables (i.e. 1.997) was the smallest. Thus, LL and LS were the most similar variables joined to form the first cluster. Neither variable has been previously clustered (the 
Rescaled Distance Cluster Combine

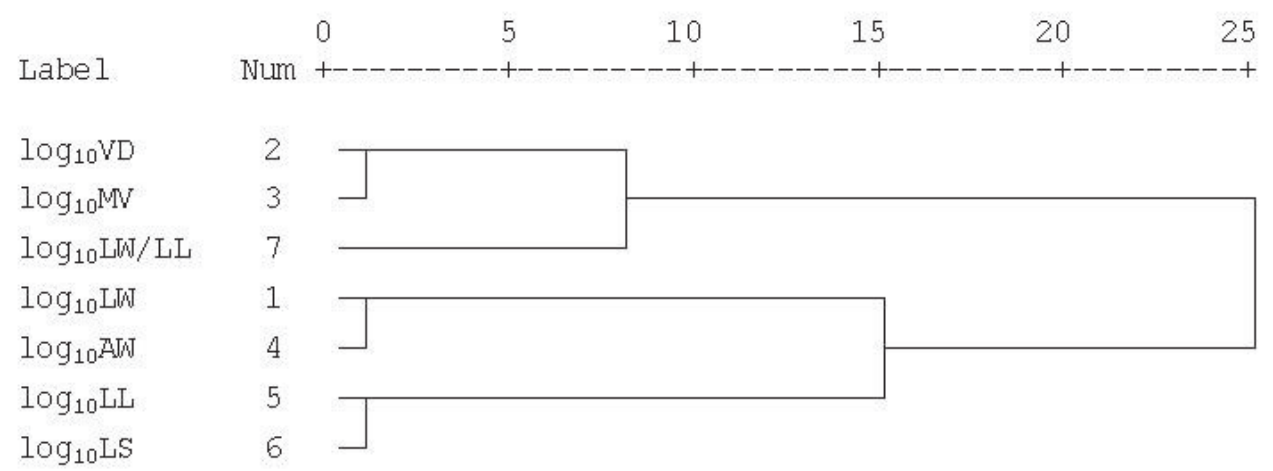

Fig. 5. A dendrogram showing the results of the hierarchical cluster analysis for leaf characters from Pančevo site (polluted site).

two zeros under Cluster 1 and Cluster 2), and the next stage when the cluster containing variable LL combines with another variable (i.e. $\mathrm{LW}$ ) is Stage 5.

In both samples, a tree structure graph known as a dendrogram (Figure 5 and Figure 6) was performed to list all of the variables and to indicate at what level of similarity any two clusters were joined.

In this study, at both sites, the last two clusters formed are: 1) VD, MV, LW/LL and 2) LW, LL, AW and LS. Furthermore, we found both, chaining and pairwise patterns of joining variables in the samples analysed. Precisely, the sequential joining of individual variables such as LW/LL with VD and MV is known as chaining. However, the joining of variables LL and LS with variables $L W$ and AW indicates that clusters were joined pairwise.

\section{DISCUSSION}

Assessing the impacts of environmentally-generated stress factors on natural plant and animal populations is very complex and difficult task because organisms in the environment are exposed to a diverse range of uncontrolled variables such as weather conditions, parasites, predators, complex mixtures of pollutants. Moreover, within the environment, the synergistic and antagonistic effects of these factors exist and they are not always fully understood.

This study revealed that there are differences in the external morphology of the Plantago major L. (ssp. major) fully developed leaves collected from natural populations exposed to different environmental conditions.

In the polluted site (Pančevo) the leaves have a different form compared to the leaves from reference unpolluted area (Vinci village). This finding is consistent with similar results reported by Bookstein (33) who indicated that when a character is allometric then a change in size produces a change in form. Thus, in the reference area (Vinci village) leaves have significantly longer leaf-blade length and they are significantly broader compared with leaves from polluted site (Pančevo). However, in Pančevo site, Plantago major L. (ssp. major) plants have leaves with a

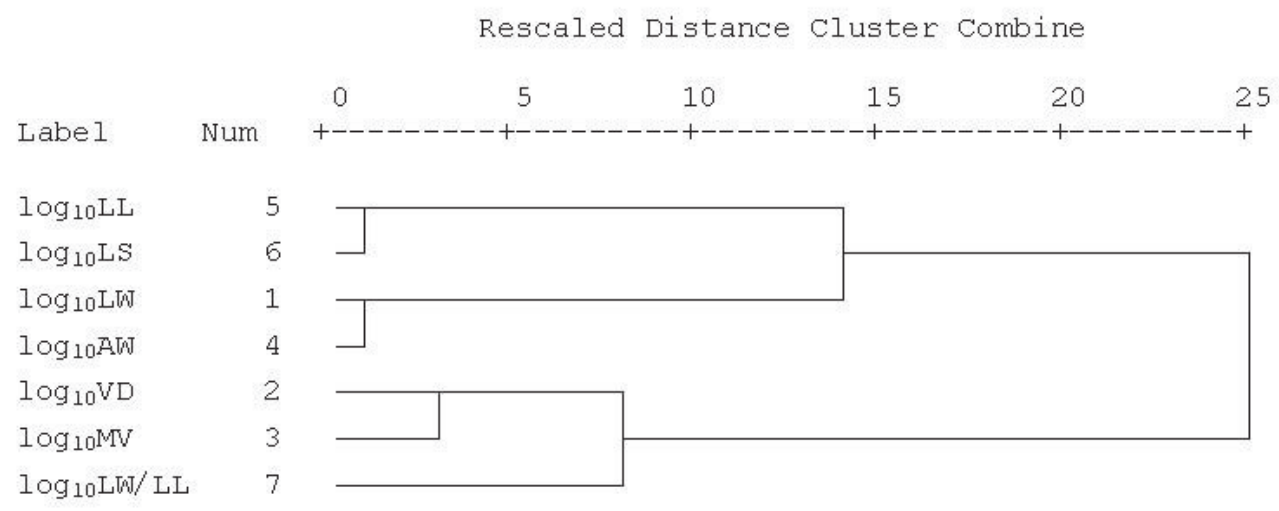

Fig. 6. A dendrogram showing the results of the hierarchical cluster analysis for leaf characters from Vinci village (reference site). 
smaller, but narrower leaf-blade length. Additionally, these leaves tend to have a larger petiole size.

According to (34), an organism's ability to function in different environments requires the ability to track and respond to environmental change. Our results showed that a stunted growth pattern (i.e. negative allometry) for the leaf-blade length was observed at both investigated sites. The fact that there was not a significant difference between coefficients of allometry (slopes) may indicate that allometric relationship between leaf-blade length versus leaf size is character specific.

However, we also found that slopes were significantly different between samples for two characters (VD and LW/LL). Therefore, we postulated that statistically significant differences in allometric relationships between samples also demonstrate the difference in strategies to maximize fitness used by plants across different environmental conditions with variations in the characters studied.

Besides, fitness is related to "a suite of traits and their interactions" (35). As proposed by Schlichting and Pigliucci (36) "considering how traits are integrated within plants increases our understanding of how plants respond to environmental variables". Trait linkages can arise as the result of structural coordination if traits share a genetic, developmental, anatomical, and/or allometric basis (37). According to (38), the most developmentally integrated complexes of traits should be the most able to maintain functionality and to accommodate the effects of stress during ontogeny.

Moreover, the results of a comparison between slopes indicated that for VD the difference between the two investigated sites was statistically significant whereas the results of a comparison between regression coefficients showed that for VD there was no statistically significant difference between the two investigated sites. Therefore, it is obvious that $\mathrm{VD}$ increased much more rapidly with increasing LS in the reference area than in the polluted site.

In our study, results of the cluster analysis showed that VD and LW/LL were clustered at the same level of similarity at both sites investigated. Thus, it is reasonable to assume that VD and LW/LL are developmentally and functionally integrated $P$. major leaf characters.

Additionally, the effect of stress depends closely on its timing in the organism's ontogeny $(39,40)$. It has been known that each terrestrial plant begins and ends its existence in the same physical location and that it has an "open" ontogeny (41). (42) suggested that there are "windows of vulnerabity" for each organism, during which the development of an organism is particularly susceptible to environmental change. Even minor perturbations during development can lead to large changes in body shape (43) and that traits that are differentially expressed through development or across resource gradients should be related to size (9). On the basis of the obtained results is our opinion that the differences between samples in P. major fully developed leaves may result from the availability, intensity and type of environmental stressors to interact with the developmental stability mechanisms of each trait separately.

Also, different traits develop in part at different time points (44). During late growth, exposure to stress affects a small group of late maturing, and weakly integrated traits (45). However, early exposure to stress makes ontogeny of morphological structures more amenable to modification (46) and also can direct morphological variation (17). Furthermore, certain characters are developmentally more stable than others, showing little response to stress exposure, whereas other characters are highly variable under "optimal" conditions (47). Accordingly, it is possible that an accelerated growth pattern (i.e. positive allometry) for the variable expressing VD under optimal growth conditions occurred early in ontogeny. Energy consumption for an accelerated growth pattern imposes a distinct developmental stress (48). So, it seems that morphological variation in Plantago major L. (ssp. major) leaves between samples, as found in this study, can also be explained by the fact that later developed trait(s) could be directed by stress induced effects on earlier developed trait(s).

The results of CV revealed that VD was a more variable measure than LW/LL. This finding is similar to those reported by (17), obtained on Sorex monticolus, Sorex vagrans, Sorex cinereus and Sorex hayi, indicating that functionally integrated complexes of traits retained their functionality even when their individual components varied under stressful condition.

The data suggest that variable expressing VD in Plantago major L. (ssp. major) leaves is under more selective pressure to adapt to stressful conditions then LW/LL. According to (49), environmental stress increases the genetic variability of many quantitative characters including life history and morphology. By increasing the amount of the genetic variation expressed in the population, stress would increase the adaptive potential and thereby the probability of its survival in adverse environments (50).

Adverse environmental conditions may affect the evolutionary process at a range of different levels, and tend to facilitate adaptation to these scenarios (51). Although cosmopolitan in distribution, in Plantago major L. there is local adaptation of populations (18).

In the present study, we found that leaf size is significantly related to both, developmental and environmental conditions. Therefore, the possibility of local adaptation can explain the tendency towards decreased size in P. major leaves from the reference natural area to chronically polluted environment. This finding is consistent with 
similar results reported by Veličković and Perišić (11), Veličković and Savić $(13,15)$ indicating that plant species such as Plantago major L. (ssp. major) should be considered as reliable bioindicators in environmental quality monitoring studies.

Acknowledgements: Ministry of Education and Science of the Republic Serbia supported this work. We thank Mrs. Marija Velickkovic for assistance with field work and character measuring.

\section{REFERENCES}

1. SNELL O 1862 Die Abhängiegkeit des Hirngewichts von dem Körpergewicht und den geistigen Fähigkeiten. Arch Psyhiatr 23: 436446 http://dx.doi.org/10.1007/BF01843462

2. THOMPSON D W 1917 On growth and form. Cambridge University Press, Cambridge, p 793 http://dx.doi.org/10.5962/bhl.title. 11332

3. HUXLEY J 1932 Problems of relative growth. London: Methuen $\&$ Co.

4. KLINGENBERG C P 1996 Multivariate allometry. In: Marcus L F, Corti M, Lay M, Naylor G J P, Slice D E (eds). Advances in Morphhometrics. Plenum Press, New York, p 23-49 http://dx.doi. org/10.1007/978-1-4757-9083-2_3

5. DUNBAR-CO S, SPORCK M J, SACK L 2009 Leaf trait diversification and design in seven rare taxa of the Hawaiian Plantago radiation. Inter J Plant Sci 170: 61-75

6. SACK L, SCOFFONI C, MCKOWN A D, FROLE K, RAWLS M, HAVRAN C, TRAN H, TRAN T 2012 Developmentally based scaling of leaf venation architecture explains global ecological patterns. Nat Comm 3: 1-10

7. JOHN G P, SCOFFONI C, SACK L 2013 Allometry of cells and tissues within leaves. Am J Bot 100: 1936-1948

8. ACOSTA-GALLO B, CASADO M A, MONTALVO J, PINEDA F D 2011 Allometric patterns of below-ground biomass in Mediterranean grasslands. Plant Biosyst 145: 584-595

9. BONSER S, AARSSEN L W 2003 Allometry and development in herbaceous plants: Functional responses of meristem allocation to light and nutritient availability. Am J Bot 90: 404-412 http://dx.doi. org/10.3732/ajb.90.3.404

10. FREEMAN D C, GRAHAM J H, TRACY M, EMLEN J M, ALADOS C 1999 Developmental Instability As A Measure Of Assessing Stress in Plants: A Case Study Using Electromagnetic Fields And Soybeans. Int J Plant Sci 160: S157-S166

11. VELIČKOVIĆ M, PERIŠIĆ S 2006 Leaf fluctuating asymmetry of common plantain as an indicator of habitat quality. Plant Biosyst 140: 138-145 http://dx.doi.org/10.1080/11263500600756322

12. VELIČKOVIĆ M 2007 How to conduct valid experiments in environmental stress/pollution monitoring studies: stumbling-blocks and sampling designs. Rivista di biologia- Biology Forum 100: 136141

13. VELIČKOVIĆ M, SAVIĆ T 2010 Developmental stability and morphological differences in Plantago major L. leaves under contrasting environmental conditions. Plant Biosyst 144: 692-702 http:// dx.doi.org/10.1080/11263504.2010.496203

14. VELIČKOVIĆ M 2010 Reduced developmental stability in Tilia cordata leaves: effects of disturbed environment. Period Biol 112: 273-281

15. VELIČKOVIĆ M, SAVIĆ T 2012 Patterns of leaf asymmetry changes in Plantago major L. (ssp. major) natural populations expos- ed to different environmental conditions. Plant Species Biol 27: 5968 http://dx.doi.org/10.1111/j.1442-1984.2011.00328.x

16. TOŠKOVIĆ D, VELIČKOVIĆ M 2013 Comparison of allometric relationships and morphological differences in Tilia cordata Mill. outer leaves exposed to different environmental conditions. Plant Biosys 147: 611-619 http://dx.doi.org/10.1080/11263504.2012.760 496

17. BADYAEV A V, FORESMAN K R, YOUNG R 2005 Evolution of morphological integration: Developmental accommodation of stress induced variation. Am Nat 166: 382-395

18. MORGAN-RICHARDS M, WOLFF K 1999 Genetic structure and differentiation of Plantago major reveals a pair of sympatic sister species. Mol Biol 8: 1027-1036

19. JANKOVIĆ M, GAJIĆ G 1974 Plantaginaceae In: Josifović M (ed) Flora of Serbia. Serbian Academy of Sciences and Arts, Belgrade, $\mathrm{p}$ 318-335

20. EL-BAKATOUSHI R 2004 Population genetics and evolution of the Plantago major group. ( $\mathrm{PhD}$ thesis), University of Newcastle, UK.

21. GURIB-FAKIM A 2006 Plantago major L. http://database.prota. org/PROTAhtml/Plantago\%20major_En.htm

22. RELIĆ D, SAKAN S, ANDJELKOVIĆ I, PANTELIĆ A, POPOVIĆ A, DJORDJEVIĆ D 2013 As, Hg and Se contents in the alluvial sediment and mud samples after conventional, microwave and ultrasonic techniques of BCR sequential extraction. Paper presented at the $17^{\text {th }}$ International Symposium on environmental pollution and its impact on life in the Mediterranean region. September 28 - October 1, 2013. Istanbul-Turkey.

23. VELIČKOVIĆ M 2004 Chromosomal aberrancy and the level of fluctuating asymmetry in black-striped mouse (Apodemus agrarius): effects of disturbed environment. Hereditas 140: 112-122 http:// dx.doi.org/10.1111/j.1601-5223.2004.01827.x

24. PLANOJEVIĆ I, TEODOROVIĆ I, BARTOVA K, TUBIĆ A, JURCA T, KOPF W, MACHAT J, BLAHA L, KOVAČEVIĆ R 2011 Wastewater canal Vojlovica, industrial complex Pančevo, preliminary ecotoxicological assessment of contaminated sediment. J Serb Chem Soc 76: 459-478 http://dx.doi.org/10.2298/JSC100505036P

25. DRAGIĆEVIĆ S, MÉSÁROS M, DJURDJIĆ S, PAVIĆ D, NOVKOVIĆ I, TOŠIĆ R 2013 Vulnerability of National Parks to natural hazards in the Serbian Danube region. Polish J Environ Studies 22: 1053-1060

26. VERWIJST T, WEN D Z 1996 Leaf allometry of Salix viminalis during the first growing season. Tree Physiol 16: 655-660 http:// dx.doi.org/10.1093/treephys/16.7.655

27. PETZ B 1970 Osnovne statističke metode. Izdavački zavod Jugoslovenske akademije znanosti i umjetnosti, Zagreb, p 1-312

28. VANDERBURGH P 2002 Two important cautions in the use of allometric scaling: The common exponent and group difference principles. Meas Phys Educ Exerc Science 2:153-163 http://dx.doi. org/10.1207/s15327841mpee0203_2

29. GOLDMAN C A, SNELL R R, THOMASON J J, BARTHOLOMEW B D 1990 Principles of allometry. In: Goldman C A (ed) Tested studies for laboratory teaching, Proceedings of the eleventh workshop/conference of the Association for biology laboratory education (ABLE), p 1-195

30. MINOS G, KOKOKIRIS L, KENTOURI M 2008 Allometry of external morphology and sexual dimorphism in the red porgy (Pargus pargus). Belg J of Zool 138: 90-94

31. ZAR H J 1999 Biostatistical Analysis - 2 $2^{\text {nd }}$ ed. In: Prentice Hall, New Jersey, p 663

32. FISHER R A 1921 On the probable error of a coefficient of correlation deduced from a small sample. Metron 1: 3-32 
33. BOOKSTEIN F L 1991 Morphometric tools for landmark data: Geometry and biology. Cambridge University Press, New York, p 435

34. WADDINGTON C H 1941 Evolution of developmental systems. Nature 147: 108-110 http://dx.doi.org/10.1038/147108a0

35. CLAUSEN J D, KECK D, HEISEY W M 1948 Experimental studies on the nature of species. III. Environmental responses of climatic races of Achillea. Carnegie Institution of Washington Publication, Washington, p 520

36. SCHLICHTING C D, PIGLIUCCI M 1998 Phenotypic evolution: a reaction norm perspective. Sinauer Associates, Sunderland, Massachusetts, USA, p 387

37. SACK L, COWAN P D, JAIKUMAR N, HOLBROOK N M 2003 The "hydrology" of leaves: co-ordination of structure and function in temperate woody species. Plant Cell Environ 26: 1343-1356

38. SIEGAL M L, BERGMAN A 2002 Waddington's canalisation revisited: Developmental stability and evolution, 99: 10528-10532 Proceeding of the National Academy of sciences of the USA.

39. HUETHER G 1996 The central adaptation syndrome: Psychosocial stress as a trigger for adaptive modifications of brain structure and brain function. Prog Neurobiol 48: 569-612 http://dx.doi. org/10.1016/0301-0082(96)00003-2

40. BADYAEV A V 2005 Role of stress in evolution: From individual adaptability to evolutionary adaptation. In: Hallgrimsson B, HALL B K (eds) Variation: A hierarchical examination of a central concept in biology, Academic Press, San Diego, p 277-302

41. NIKLAS KJ 1994 Plant allometry: The scaling of form and process, University Press, Chicago IL, p 395

42. VRIJENHOEK R C 1994 Transcription of round-table discussion. In: Markow T A (ed) Developmental Instability: Its Origins and Evolutionary Implications. Dordrecht, Kluwer, p 391
43. EMLEN D J, NIJHOUT H F 2000 The development and evolution of exaggerated morphologies in insects. Ann Review of Entom 45: 661-708 http://dx.doi.org/10.1146/annurev.ento.45.1.661

44. VAN DONGEN S 2006 Fluctuating asymmetry and developmental instability in evolutionary biology: Past, present and future. $J$ Evol Biol 19:1727-1743 http://dx.doi.org/10.1111/j.1420-9101. 2006.01175.x

45. REICHLING T D, GERMAN R Z 2000 Bones, muscles and visceral organs of protein-malnourished rats (Rattus norvegicus) grow more slowly but for longer durations to reach normal final size. $J$ Nutrition 130: 2326-2332

46. HANKEN J, KLYNKOWSKY M W, ALLEY K E, JENNINGS D H 1997 Jaw muscle development as evidence for embryonic repatterning in direct-development frogs. Proceedings of the Royal Society of London B, 264: 1349-1354 http://dx.doi.org/10.1098/ rspb.1997.0187

47. CLARKE G M 1995 The genetic basis of developmental stability. II Asymmetry of extreme phenotypes revisited. Am Nat Biol 7: 94104 http://dx.doi.org/10.1086/285821

48. MØLLER A P, ERIKSSON M 1994 Patterns of fluctuating asymmetry in flowers: Implications for sexual selection in plants. J Evol Biol 7: 97-113

49. HOFFMANN A A, PARSONS P A 1997 Extreme environmental change and evolution. Cambridge University press, Cambridge, $\mathrm{p}$ 261

50. IMASHEVA A, LOESCHCKE V, ZHIVOTOVSKY L E, LAZEBNY O E 1998 Stress temperatures and quantitative variation in Drosophila melanogaster. Heredity 81: 246-253 http://dx.doi. org/10.1046/j.1365-2540.1998.00384.x

51. MØLLER A P, SWADDLE J P 1997 Asymmetry, developmental stability, and evolution. Oxford University press, New York, p 291 